\title{
En stor, lykkelig familie
}

Sosiale medier og nettsamfunn er webløsninger der det legges til rette for dialog, interaksjon og kunnskapsdeling. Samtale om sykdom er blitt en viktig del av mange av disse. Det finnes flere nettsamfunn som er bygd opp rundt en eller flere spesifikke diagnoser. PatientsLikeMe.com er et av de mest kjente. Det er ikke nytt at pasienter har bred tilgang på informasjon om egen sykdom via nettet, men med sosiale medier har de også fått en mulighet til globalt å utveksle erfaringer med andre i samme situasjon. De sosiale mediene distribuerer makten og setter oss i stand til selv å ta mer ansvar for å finne gode måter å leve med sykdom eller behandle den. Som følge av dette ønsker ikke pasientene bare å være i sentrum, de vil sitte i førersetet, skrev Charlotte Haug i en leder nylig. Hun oppfordrer leger til å tenke gjennom hva dette gjør med legerollen (1).

Legen som portvakt og forvalter av kunnskap om sykdom og behandling marginaliseres. Heldigvis, vil mange si. Problemstillingen har også tidligere vært diskutert i Tidsskriftets blogg. I posten Hvorfor helsevesenet bør bry seg om sosiale medier trekker lege og blogger Maria Gjerpe frem mulighetene sosiale medier gir for brukermedvirkning (2). Allmennlege Elisabeth Swensen peker i kommentarfeltet i den samme posten på konsekvensen dette i verste fall kan ha for legene når pasienten har lest seg opp, diskutert og selv funnet løsningen på nett. «Å ta pasienten på alvor» betyr ikke at pasienten selv skal sette diagnose og forordne behandling. Det betyr i praksis å plassere legen i rollen som nyttig idiot og/eller gissel, skriver hun og argumenterer for at legen må ha rett til å praktisere faget sitt og være uenig med pasientene dersom dette er deres faglige overbevisning.

Tidsskriftenes rolle som formidler av ny fagfellevurdert forskning om god behandling og legemidler settes også under press av denne nye virkeligheten. Når pasienten «bestiller egen behandling», blir også informasjon til legene gjennom artikler i vitenskapelige tidsskrifter mindre viktig. Redaksjonell og faglig kvalitetssikring av innholdet og etiske standarder, som for eksempel at forfatternes eventuelle interessekonflikter skal oppgis, settes til side av ønsket om å imøtekomme en pasient som har lest om og diskutert en ny behandlingsmetode i et internasjonalt nettsamfunn. PatientsLikeMe oppfordrer legemiddelindustrien til å benytte nettsamfunnet blant annet til å skaffe seg kunnskap om markedet og til rekruttering til kliniske studier. Grunnleggerne mener tempoet i den medisinske forskningen er for lavt, blant annet som følge av for strenge forskningsetiske krav rundt anonymisering. De oppfordrer til åpenhet om symptomer, behandling og reaksjon på behandling slik at informasjonen kan komme raskere frem til aktører i legemiddelindustrien og beslutningstakere i helsevesenet. Målet er å få ny og effektiv behandling på markedet i ekspressfart (3). Samtidig som legens og tidsskriftenes tradisjonelle portvaktroller svekkes, fjerner altså sosiale medier barrierene for direkte kontakt mellom legemiddelindustrien og pasientene.

Det er gratis å delta i diskusjonene om sykdommer i sosiale medier. I mange av disse kan man opptre anonymt, og ingen stiller spørsmål ved din bakgrunn eller dine hensikter. Det er heller ikke uvanlig at bedrifter benytter innflytelsesrike bloggere til å omtale produkter. Bloggeren har ikke samme etiske regelverk som for eksempel presse og tidsskrifter har, for å gjøre leserne oppmerksom på hva som er reklame og hva som er redaksjonelt kvalitetssikret stoff. Forbudet mot annonsering for reseptbelagte legemidler mot pasienter blir irrelevant og gammeldags når industrien kan gå direkte i dialog med pasientene om sykdommer som preger livet deres.

Den norske Facebook-siden Spør legen om migrene (4) er også en god illustrasjon på denne nye virkeligheten. Siden ble opprettet i juni 2010, og den har nå nærmere 600 tilhengere som har mulighet til å stille spørsmål om migrene gratis rett til en lege. De slipper å stå frem med navn fordi de kan sende melding, og få innlegget anonymisert. Selve spørsmålet og svaret er åpent for alle. Det er Norsk migreneforbund som står bak siden. Samtalene dreier seg mye om behandling, både med legemidler og uten, og litt om erfaringer med å leve med migrene. Den gir makt og muligheter til pasientene og setter dem i stand til å møte egen lege med kunnskap om mulig behandling.

Det er velkjent at pasientorganisasjonene mottar støtte fra legemiddelindustrien. Derfor er det heller ikke usannsynlig at en eller flere av Norsk migreneforbunds velgjørere har en finger med i spillet i den vellykkede Facebook-siden om migrene. Logikken er enkel. Jo mer oppmerksomhet man klarer å skape rundt hodepine, desto mer medisin selges det. Når totalsalget øker, selges det også mer av den enkelte produsents medisin. På Facebook er oppmerksomheten gratis, og du når toppmotiverte mottakere midt i målgruppen. Det er interessant å merke seg at i flere av svarene på Facebook-siden anbefaler legen pasienten å laste ned materiell fra www.oslomigreneklinikk.no. Denne migreneklinikken er tilfeldigvis hennes egen.

Måten sosiale medier distribuerer makt på er fascinerende, men den åpner også for at aktører med kommersielle interesser kan påvirke oss mer effektivt og subtilt enn tidligere. Tradisjonelle filtre for kvalitetssikring forvitrer. Uten selv å delta er det vanskelig å forstå hvordan de sosiale mediene muliggjør direkte dialog mellom pasienter, lege-pasient og legemiddelindustrien.

\section{Stine Bjerkestrand}

stine.bjerkestrand@legeforeningen.no

\section{Stine Bjerkestrand er utviklingsredaktør i Tidsskriftet og cand.mag. med} journalistikk, medievitenskap og statsvitenskap i fagkretsen.

Litteratur

1. Haug C. De nye pasientene. Tidsskr Nor Legeforen 2010; 130: 1011.

2. Hvorfor helsevesenet bør bry seg om sosiale medier. Tidsskriftets blogg 21.12 2010. http://blogg.tidsskriftet.no/2010/12/hvorfor-helsevesenet-bør-bry-segom-sosiale-medier/

3. PatientsLikeMe. http://partners.patientslikeme.com/about/ (21.2. 2011)

4. Spør legen om migrene. Facebook. www.facebook.com/migrenelegen (21.2. 2011) 